\title{
Management and promotion of economic innovation potential
}

\author{
Raisa Krayneva \\ Faculty of Volga Region, State University of Service \\ Togliatti, Russia \\ raisa-krayneva@yandex.ru
}

\section{Alexandr Bugaev}

Faculty of Volga Region, State University of Service

Togliatti, Russia

zueraichi@yahoo.com

\section{Tatyana Zhuravleva}

Faculty of Volga Region, State University of Service

Togliatti, Russia

tatiana502007@yandex.ru

\section{Sergej Vojtovič}

Alexander Dubcek University

Trenčin, Slovakia

sergej.vojtovic@tnuni.sk

Abstract. Our paper focuses on scrutinizing the determinants and the structure of economic innovative potential as well as the existing methods of its assessment at the macroeconomic level. We employ a case study of Russian Federation to tackle these issues and to analyze the problems associated with developing and managing economic potential. The paper analyzes the selection and placement in world research rakings, ratings, and indices, as well as the dynamics of change in the indicators characterizing the innovative potential in research and development issues. Our results enable us identify and reveal the key issues and the main problems of research and development potential and to formulate the comprehensive contingency strategic management plan along with the directions and guidelines of innovative development for the years to come. Our findings reveal the main problems in the development of economic innovative potential of Russian Federation and help us to formulate policy implications for the longterm economic horizon. 
Keywords: innovation potential, global competitiveness, international indexes, ratings, knowledge economy, innovation development, Russian Federation

JEL Classification: O32, Q55

\section{INTRODUCTION}

In contemporary economy, creative innovation brought about by economic subjects and structures of domestic economy comes forward as one of its main priorities. Based on the innovative activity of economic agents and business enterprises, the synergy effect promoting transition for "the economy which is traditionally catching up" on an innovative trajectory of development can become a reality.

Being the "successor" of the Soviet-style planned economy, Russian economy is characterized by domination of the entities of the oil \& gas complex and also mining industry entities (Lisin and Strielkowski, 2014; Abrhám et al., 2015). The economy is distinguished by dual nature: on the one hand, it is oriented on rather extensive development of raw industries with low performance, on the other - it possesses high potential of development - scientific and technical, personnel, information. Therefore, special relevance is given to the tasks of creating the prerequisites for overcoming the historical heritage of raw production orientation, upgrade of industrial enterprises on the basis of innovative technologies' use for the purposes of competitive high-tech production. With regard to the above, we put forward the following research objectives:

- To determine the nature, types and structure of innovations and innovative capacity

- To compare Russia to the other countries of the world (2014-2015 data) using the values of existing indices and indicators of innovative potential.

- To formulate the directions in Russia's innovation potential development in the long term.

The main goal of this paper is to analyze and describe the process of formation and development of Russian economic innovation potential. The scope of our research covers the economic relations arising in the process of its formation and development.

\section{INNOVATION IN THE ECONOMIC LITERATURE}

The term "innovation" appeared in the 19th century in a social and cultural context for designation of entering of some elements of one culture in another. At the beginning of the $20^{\text {th }}$ century, Kondratyev began studying of regularity of technical innovations owing to what the term "innovation" has purchased economic content.

Josef Schumpeter has determined concept of innovations as "implementation of new combinations" by the entrepreneur for generation of profit; and business activity as the innovative and being a fixed source of competitive restructuring economies and economic growth.

According to Druker's opinion, the innovation is a "development and deployment new by means of which wellknown elements will give new outlines to economy of this business. These elements will receive absolutely new economic measurement. The innovation is focused on efficiency, and in business - on cost efficiency" (Druker, 2007).

In Russian economic literature along with the term "innovation" such definitions as "innovation", "innovation", "innovation" are used, at the same time, as a rule, there is their identification (Akhtyamov, 2009; Batkovsky, 2009; Rosenthal, 2010). 
In our opinion, the concepts "innovation" and "innovation" should be differentiated for the following reason:

- innovation acts as the arranged result of basic, applied researches, developments and experimental works in any field of activity on increase of its efficiency. Innovations can be arranged in a type: opening, patents, trademarks, improvement suggestions, documentation on a new or advanced product, etc.;

- innovation represents process of implementation of an innovation for the purpose of development (change) of object of management and receipt of scientific and technical, economic and social effects (Etzkowitz, 2000; Trott, 2008; Gareyev, 2009; Fedotovsky, 2009).

Thus, in this paper we attempt to identify the resulting effect of implementation of innovations for the purpose of development and meaningful management as well as for achieving economic, social or other type of effect represented by innovations (Omonov, \& Veretennikova, 2016; Mamedov et al., 2016).

Nowadays, there is a set of classification models of the innovations offered by foreign and Russian scientists (Stepanenko, 2004; Leydesdorff. 2000; Overdorf, 2007). Determination of a set of parameters of innovations is based on various approaches to classification of the considered phenomenon. However, it is possible to allocate the most essential signs of innovations which allow us to classify them (Table 1).

First of all, innovations can be basic, i.e. leading to radical changes of all productive and economic system, and improving, directed to change of this or that subsystem of productive and economic system (Koudelková et al., 2015; Strielkowski et al., 2016; Mishchuk et al., 2016). Furthermore, the basic and improving innovations can be technological, organizational and managerial or marketing. At the entities achievement of a certain efficiency which is differentiated as economic, social, ecological is result of the implemented innovations (Trukhachev et al., 2016).

One of the most important properties of innovations is dynamism, variability therefore innovations are considered from a line item of the process approach. Thence, the following characteristic of the innovative process representing a set of three stages can be classified as follows:

- from researches before the first production development;

- from the first development before expansion of release in the scales sufficient for satisfaction of requirement of all national economy;

- from production of an innovation before its use by final consumers, including servicing and utilization of the used product.

Further determination of innovative process has been expanded and specified: "the dynamic and positively estimated interaction between the innovator and external environment (economic, social, political, etc.) as a result of the change of a condition of practical activities which is purposefully performed by the innovator owing to application to it the new or not used in the field knowledge" (Gareyev, 2006).

Subjects of the market, including, industrial enterprises, in modern conditions pass to the pro-active strategy of development oriented to significant influence and change of a market situation and its components. Innovative process is consistently performed in spheres of science, equipment, production and consumption and has shorter lifecycle that is connected to the increase of dynamics of changes in the last decades 20th century and the beginning of the $21^{\text {st }}$ century (Kodama, 1995; Strielkowski \& Weyskrabova, 2014; Chernov, Dorokhova, \& Dorokhov, 2016).

We will note that the main effect of an innovation is that the modern innovative entity provides effective functioning and high growth rates of technical and economic indicators. By some estimates, the radical innovative projects connected with implementation of new products and technologies (basic technological innovations) can give a business performance surplus for 50-100\%. Structural changes (basic organizational and managerial and marketing innovations) are capable to lead to growth of efficiency by 30 - 
$60 \%$ due to increase of efficiency of production and auxiliary processes, and also implementation of new mechanisms of promotion of products on the market. Fast-implementable allowances in the form of the improving innovations give growth of efficiency by 10-30\% (Hammer \& Champi, 2005; Belousov, 2006; Tolmacheva, 2011).

Table 1

Classification of innovations

\begin{tabular}{|c|c|c|}
\hline Author & Classification sign & Innovation types \\
\hline \multirow[t]{5}{*}{ Prigozhin (2003) } & On prevalence & Single. Diffusion. \\
\hline & In the place in production cycle & $\begin{array}{l}\text { Raw. Providing. } \\
\text { Product. }\end{array}$ \\
\hline & On succession & $\begin{array}{l}\text { Replacing. Canceling. } \\
\text { Returnable. Opening. } \\
\text { Retro-introductions. }\end{array}$ \\
\hline & On a scope of the expected market share & $\begin{array}{l}\text { Local. System. } \\
\text { Strategic. }\end{array}$ \\
\hline & $\begin{array}{l}\text { On the innovative potential and degree of } \\
\text { novelty }\end{array}$ & $\begin{array}{l}\text { Radical. Combinatory. } \\
\text { Enhancing. }\end{array}$ \\
\hline $\begin{array}{l}\text { Christensen } \\
\text { Clayton (2010) }\end{array}$ & On nature of technological novelty & $\begin{array}{l}\text { "Blasting" (revolutionary). } \\
\text { Supporting (evolutionary) }\end{array}$ \\
\hline Van Dane (2000) & $\begin{array}{l}\text { On nature of influence on the market } \\
\text { (forming of the new markets or } \\
\text { expansion of available) }\end{array}$ & $\begin{array}{l}\text { The main product } \\
\text { The supplementing product }\end{array}$ \\
\hline \multirow[t]{4}{*}{$\begin{array}{ll}\text { Gorshkov } & \text { and } \\
\text { Kretova (2000) }\end{array}$} & According to structural characteristics & $\begin{array}{l}\text { Innovations on "entrance". } \\
\text { Innovations at "exit". } \\
\text { Innovations of system structure }\end{array}$ \\
\hline & On a field of activity (target changes) & $\begin{array}{l}\text { Technological. } \\
\text { Production. } \\
\text { Economic. Social. } \\
\text { In the field of management. }\end{array}$ \\
\hline & On objects of an innovation & $\begin{array}{l}\text { Resources. Technologies. } \\
\text { Processes. Products. } \\
\text { Management and organization. } \\
\text { External and internal environment. }\end{array}$ \\
\hline & To destination & $\begin{array}{l}\text { Scientific and technical. } \\
\text { Production. } \\
\text { Consumer. Commercial. }\end{array}$ \\
\hline \multirow[t]{3}{*}{ Utkin et al. (2000) } & On nature of the satisfied requirements & $\begin{array}{l}\text { Orientation on the existing } \\
\text { requirements. Orientation on } \\
\text { forming of new requirements. }\end{array}$ \\
\hline & In a subject and a sphere of application & $\begin{array}{l}\text { Product. Market. } \\
\text { Innovations processes. }\end{array}$ \\
\hline & On origins & Jet. Pro-active. \\
\hline \multirow{3}{*}{$\begin{array}{l}\text { Gokhberg } \\
\text { Ilyenkova (2004) }\end{array}$} & In technological parameters & Product. Process. \\
\hline & On novelty & $\begin{array}{l}\text { New to an industry in the world. } \\
\text { New to an industry in the country. } \\
\text { New to the entity. }\end{array}$ \\
\hline & On radicalism degree (depth of changes) & $\begin{array}{l}\text { Basic. Improving. } \\
\text { Modification. }\end{array}$ \\
\hline
\end{tabular}

Source: Own results 
Consideration of regularities of expansion and replacement of the technological ways mediating a technical and economic condition of a social production allows to prove strategic directions of development of new technological way in Russia. First of all, it should be noted that innovative industries were not created completely yet, there is a competition of alternative technologies, with respect thereto, domestic enterprises have a chance to take leadership on the perspective directions of formation of new technological way and by that "to ride out" the ascending flows of a new long wave of economic growth. However, as show statistical data, the number of the researches conducted in the field of modern technologies there is not enough for ensuring leadership in the world market.

According to some estimates from the USA, the share of the production characteristic of the fourth technological way constitutes about $20 \%$, the fifth $-60 \%$ and already more than $7 \%$ are the share of technologies of the sixth TU (Dementieva, 2006). For comparison, in Russia the share of the production corresponding to the third TU constitutes about $30 \%$, the fourth - over $50 \%$, the fifth - less than $20 \%$.

The share of Russia in universal technological sector constitutes about $0,3 \%$, and in the market of nanotechnologies $-0,04 \%$. In many respects this fact is explained by the fact that Russia has joined in researches in the field of nanotechnologies for 7-10 years later. As a result, now Russia considerably lags behind world leaders of an industry - the USA, Japan and EU countries both on Research and Development indicators, and on commercialization of inventions.

Innovative processes in economy are caused by the competition on a commodity market and services. However, being the generator of innovations, the market in view of essential instability and variability is not capable to start innovative processes in the necessary directions and scales, is not capable to provide uniformity and a continuity of process of innovative development in economy. For start of innovative process of one competition it is not enough, competitive struggle is only the reason, a source of innovative processes, and also the conditions promoting their development, and, the most important, subjects propellers capable to connect in innovative process the new knowledge, conditions and resources constituting content of innovative capacity of the country, an industry, the entity are necessary (Algina, 2011; Čábelková \& Strielkowski, 2013).

The condition of innovative potential characterizes a capability of national economy to creation and rational use of cumulative wealth, the live and substantiated work, their optimum combination in production process (Kokurin, 2001; Mostenska et al., 2015; Nagornyak \& Vovk, 2012).

The category "innovative potential" can be treated as a capability of system to transformation of the actual order of things in a new condition for the purpose of satisfaction of the existing or again arising requirements. Therefore, innovative potential is some kind of characteristic of a capability of system to change, improvement, progress (Matveykin, 2007; Zizlavsky, 2016).

As innovative potential it is reasonable to consider not all quantity of resources which society assumes to use for the perspective development but only that their part which can be used for a growth in volumes or improvement of quality of final consumption.

Thus, innovative potential is not only available resources for ensuring innovative activities, but also mechanisms of the specified activities.

In foreign science and practice by the most widespread determination of innovations and innovative potential on the basis of the published Organization for Economic Cooperation and Development (OECD) in 2005 of the third version "Managements of Oslo" (Oslo Manual) is. "The management of Oslo" contains recommendations for collection and interpretation of data on innovations in an international comparable form and is applicable to the analysis of innovative process in member countries of OECD. 
According to the Oslo Manual, innovative potential is a result of various training processes - the conscious, purposeful, expensive, requiring a lot of time, nonlinear, multi-stage and cumulative. The most essential component of innovative potential is knowledge.

Researching essence of innovative potential, it is reasonable to address the analysis of its structure where are allocated resource, internal and productive, are important to one extent or another.

Allocation of structural characteristics of innovative potential corresponds to methodological approaches in research of innovative potential as economic category. So, supporters of resource approach come to a conclusion about need of generalization of a complex of the cumulative resources including personnel, technological, financial and scientific components that has led to emergence of keywords in determination of innovative potential - "capability" and "readiness". The resource component of innovative potential is some kind of "base" for its forming.

Supporters of productive approach have determined the reached level of innovative potential that is caused by specific economic indicators (innovative activity of the entities, patent efficiency, and security with advanced technologies, etc.).

Supporters of an internal component of innovative potential structure innovative potential on blocks and determine a capability of innovative activities to transform resources to an innovative product.

\section{METHODS OF ASSESSMENT}

In the modern world's practice, there is a considerable number of various indicators estimating a level of development of innovative activities: since an assessment of a human capital, indicators measuring knowledge, the scientific and technical progress (STP) and finishing with separate indicators of the stock market.

The existing indexes of innovative capacity of the countries of the world include, as a rule, up to 100 quantitative and high-quality variables with certain "scales" which, include education, sciences, technologies, a human capital, political and innovative climate in the country, etc. and integrate data of official national statistics, polls and expert polls.

The international organizations have developed several systems of the indicators reflecting the level of innovative capacity of the country. Among them are the following:

- Total index of innovations (Summary Innovation Index - SII) is calculated on methodology and a technique of comparison of results of innovative activities of $27 \mathrm{EU}$ countries with other countries largest on expenses on researches and developments. On SII the states are ranged on groups: "leaders of innovations", "adherents of innovations", "moderate innovators", "the catching-up innovators" (including Russia).

- Index of global competitiveness (Global Competitiveness Index, GCI). When calculating GCI all analyzed indicators break into 12 blocks reflecting basic requirements to economic systems of the countries, efficiency increase factors, factors of upgrade of economy and innovations (Global Competitiveness Report)

- Index of scientific and technical potential as a component of an integrated indicator of an assessment of level of competitiveness of the country is developed within the World economic forum. This indicator is calculated on the basis of such data as number of patents for 1 million population; a country line item on the level of technology development, a contribution of foreign investments to innovative activities of local firms; number of Internet users on 10000 people, etc.

- Index of economy of knowledge (Knowledge Economy Index, KEI). KEI estimates readiness of the countries for transition to economy of knowledge. At the same time on an index of innovations, education 
and knowledge calculated in case of calculation of an index of economy of knowledge, Russia is at the level of the backward countries.

- Index of human development (Human Development Index, HDI). In 1990 the Development program of the UN (PROON) has issued the first report on development of the person which contained the Index of human development (IChRP) calculated on the basis of three indicators: longevity, education level and level of living

- Indicators which are annually published by Organization for Economic Cooperation and Development (OECD) characterizing the level and dynamics of development of innovative economy in the developed and certain developing countries. In system of indicators of OECD the following indicators are provided:

- specific weight of high-technology sector of economy in products of processing industry and services;

- innovative activity;

- volume of investment into sector of knowledge (public and private), including expenses on the higher education, Research and Development, and also in development of the software;

- development and release of information and communication equipment, software product and services;

- number occupied in the sphere of science and high technologies, etc.

Federal State Statistics Service of the Russian Federation, making statistical observations in the field of scientific researches and innovations, fixes the following data (Federal State Statistics Service. 2008):

- number of the organizations and number of personnel (including on categories) which were carrying out researches and developments;

- internal costs on researches and developments, including on cost types and on work types;

- costs for technological innovation;

- number of researchers with academic degrees;

- number of the organizations conducting training of graduate students (doctoral candidates), and their number;

- number accepted and issued (including with defense of a thesis) from postgraduate study (doctoral studies);

- number of the submitted applications for issue and number of the granted patents for inventions and useful models;

- number created and number of the used advanced production technologies, including on their categories;

- number of the organizations performing innovative activities, and their specific weight in total number of the organizations;

- amount of innovative goods, works, services and their specific weight in a total amount of shipped goods, works, services.

\section{INDICES OF INNOVATIVE DEVELOPMENT}

According to researches of the World economic forum on innovative potential, in 2015 Russia occupied the 84 th place, and on quality of scientific researches - the 58th. Indicators remain at the same level as a few years ago. 
The economic competitiveness Russia has risen from the 53rd to the 45th place among 144 countries (table 2). Decrease in competitiveness of other countries, but not improvement of a situation in Russia was the reason of it: the assessment in points has not changed. Line items of Turkey, India, Brazil and Mexico have worsened, for example. Russia is still lower than China (the $28^{\text {th }}$ place), Kazakhstan (42 $\left.{ }^{\text {nd }}\right)$ and countries of Eastern Europe. At the same time competitiveness of developed countries lately grew, and now Russia lags behind them in a bigger degree.

Table 2

Rating of competitiveness of the world's leading economies

\begin{tabular}{|l|c|c|c|}
\hline & Place & Changes 2015/2016 & Changes 2016/2017 \\
\hline Switzerland & 1 & 0 & 0 \\
\hline Singapore & 2 & 0 & 0 \\
\hline USA & 3 & +1 & 0 \\
\hline Netherlands & 4 & +3 & +1 \\
\hline Germany & 5 & +1 & -1 \\
\hline China & 28 & -2 & 0 \\
\hline Kazakhstan & 53 & +8 & -11 \\
\hline Russia & 43 & +8 & +2 \\
\hline Brazil & 81 & -18 & -6 \\
\hline
\end{tabular}

Source: World Economic Forum, The Global Competitiveness Report 2016-2017

The strengths of Russia are the large domestic market (the 7th place) and the developed infrastructure - railway (24th), air transportation (12th) and mobile communication (18th). However, quality of education and health cares do not correspond to indicators of other countries.

Weak institutes (the $100^{\text {th }}$ place), corruption $\left(116^{\text {th }}\right)$, lack of independent justice $\left(108^{\text {th }}\right)$ remain an obstacle for development of economy. It is easy to open business in Russia (the $37^{\text {th }}$ place), but the high level of bureaucracy and administrative barriers do not allow to entrepreneurs to develop the case.

We will note that on value of the Corruption Perceptions Index, Russia in 2016 has taken already the $119^{\text {th }}$ place among the 180 countries of the world - very high level of corruption (A rating of the countries of the world on the level of perception of corruption).

According to the rating of development of the electronic government (e-government development rank) developed time in two years to the overview of a level of development of the electronic government in 193 member countries of the UN in 2012 Russia has risen directly by 32 line items - with 59 on the 27th place that was the best indicator among all countries of Eastern Europe and the CIS and the best result of Russia for all the time of existence of a rating since 2001.

As the reason of a significant growth in a general index improvement of a level of development of electronic services and a level of development of ICT - infrastructure, infrastructure of the electronic government, including upgrade of the government website, and also to active representation of interests of the Russian Federation within interaction with the international organizations has served. Creation of the Single portal of the state services - a key link of "the electronic government" of the country became the most considerable break.

Unfortunately, Russia has not improved the place in a rating in 2014, first of all, because of insufficient development of services of the electronic government.

The economy of knowledge became for Russia one of the weakest spots. The high line items in the world reached in the past in science, education, safety, etc. are lost. All components of the knowledge capital 
for the last 20 years have significantly decreased. Negative dynamics is observed on a sub-index of quality of knowledge.

\section{INNOVATION ACTIVITY OF ENTERPRISES}

The comparative analysis of information provided in Table 3 and Figure 1 allows us to draw a conclusion that the innovation of industrial production in Russia is performed by low rates.

Table 3

Main indicators of innovative organization activity of industrial production

\begin{tabular}{|l|c|c|c|c|c|c|c|}
\hline & $\mathbf{2 0 0 0}$ & $\mathbf{2 0 0 5}$ & $\mathbf{2 0 1 0}$ & $\mathbf{2 0 1 2}$ & $\mathbf{2 0 1 3}$ & $\mathbf{2 0 1 4}$ & $\mathbf{2 0 1 5}$ \\
\hline $\begin{array}{l}\text { Specific weight of the } \\
\text { organizations performing } \\
\text { technological innovations in } \\
\text { total number of the } \\
\text { organizations, \% }\end{array}$ & 10,6 & 9,3 & 9,3 & 9,9 & 9,7 & 9,7 & 9,5 \\
\hline $\begin{array}{l}\text { Amount of innovative } \\
\text { goods, works, services, in } \\
\text { real terms 1995, million } \\
\text { rubles }\end{array}$ & 32626,7 & 52546,2 & 62312,8 & 107768,0 & 125658,2 & 115878, & 114675 \\
\hline $\begin{array}{l}\text { Percentage of the total } \\
\text { amount of shipped goods, } \\
\text { the performed works and } \\
\text { services }\end{array}$ & 4,4 & 5,0 & 4,9 & 7,8 & 8,9 & 8,2 & 7,9 \\
\hline $\begin{array}{l}\text { Costs for technological } \\
\text { innovations, in real terms } \\
1995, \text { million rubles }\end{array}$ & 10462,7 & 12105,3 & 18695,9 & 25063,7 & 30541,2 & 29100,2 & 25895,3 \\
\hline $\begin{array}{l}\text { Percentage of the total } \\
\text { amount of shipped goods, } \\
\text { the performed works and } \\
\text { services }\end{array}$ & 1,4 & 1,2 & 1,5 & 1,8 & 2,2 & 2,1 & 1,8 \\
\hline
\end{tabular}

Source: Science. Innovations. Information society: 2015

The susceptibility of domestic business to innovations of technological nature remains low, in 2014 the share of the entities performing development and deployment of technological innovations has constituted $9,7 \%$ of total number that is much lower than the values characteristic of Germany, Ireland, Belgium where more than $50 \%$ of the entities are innovation-active. Moreover, the intensity of internal costs on researches and developments making 1,19\% in Russia is rather small (a similar indicator in the Republic Korea of 4,15\%, in Japan - 3,47\%, in Germany - 2,85\%). 


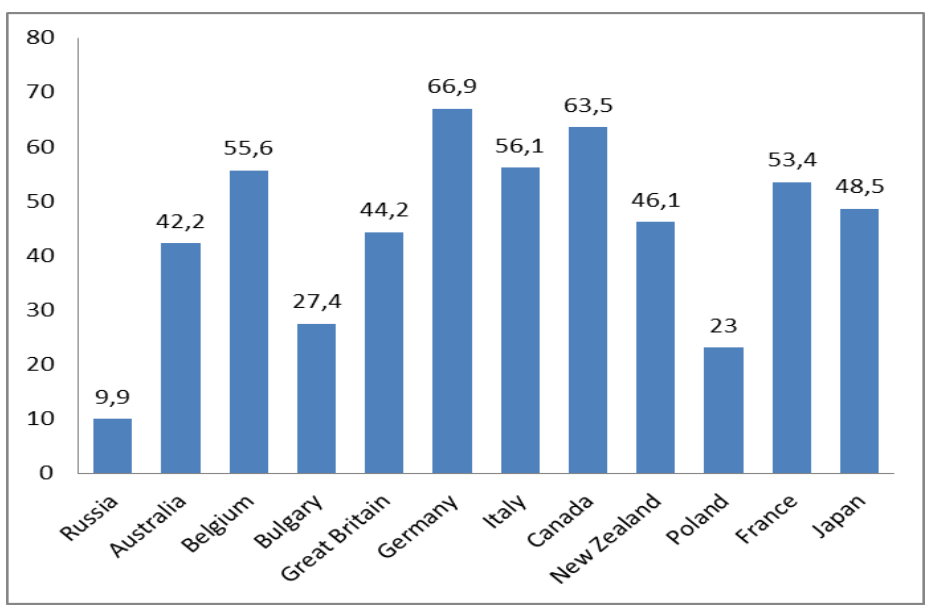

Figure 1. Specific weight of the organizations performing innovations in total number of the organizations for the countries in \%, 2015

Source: Science. Innovations. Information society: 2015

The Russian entities spend for innovations much less than the foreign competitors in the relevant sectors. In a rating of 1000 largest companies performing researches and developments only 3 Russian companies are provided: JSC Gazprom (the 108th place on absolute amount of research costs and developments, the share of costs for which in revenue constitutes $0,6 \%$ ), JSC AVTOVAZ (the 758th place, $0,8 \%$ ), JSC Sitroniks (the 868th place, 2,6\%). For comparison, a share of expenses on researches and developments in budgets of the leading companies of the world automobile industry more, than 6 times higher, than at the Russian car maker: at General Motors (the 2nd place in a rating on amount of research costs and developments) it constitutes $4,4 \%$ of revenue, at Toyota (the 4 th place in a rating) $-3,9 \%$. For the leading world telecommunication companies the corresponding indicator is ten times higher, than in the Russian leader: so, at the company at Qualcomm (the USA, the 43rd place in a rating) it constitutes 20,6\% of revenue.

We will note that in the Russian economy the steady tendency of innovative behavior of business was not created yet. Critical problems of innovative development are creation of motives of innovative behavior of all subjects of economy, ensuring their cooperation with sector of basic researches and developments, with a support on the created and developing innovative infrastructure today (Batkovsky, 2009).

\section{CONCLUSIONS AND DISCUSSIONS}

Based on the results presented above, the following outcomes and conclusions can be summarized. Overall, it appears that the main problems of management and development of innovative potential in Russian Federation are represented by the following factor and issues:

- poor formation of innovative industries, preferential development of a mining industry (share of productions of the fifth technological way less than $20 \%$ );

- high level of monopolization of economy, corruption, weakness of institutes, lack of independent justice, high level of bureaucracy and administrative barriers;

- lack of a steady tendency of innovative behavior of business, the Russian entities spend for innovations much less than the foreign competitors, a share of the innovation-active entities $-9,7 \%$; 
- insufficient funding of science and Research and Development, insufficient efficiency of educational and scientific infrastructure, the weakening of scientific and educational potential connected with aging of scientific personnel and deficit of young scientists.

In order to achieve a steady success in long-term perspective, it seems to be necessary to provide different stable flows of innovations. Productive and economic systems shall manage continuously all aspects creating capabilities to innovations (strategy of innovations, organizational structures, dynamic capabilities, competence, creativity, culture, continuous review and improvement of activities within these aspects), and also to have a set of necessary tools for this purpose (Rosenthal, 2010).

Relying on the revealed problems and tendencies, we can formulate the directions of development of innovative capacity of Russia on a long-term outlook that might be defined as follows:

- Decreasing the risks of macroeconomic instability in the country; funds;

- Improvement of quality of institutes and public administration, efficiency of an expenditure of public

- Fighting against a monopolism, corruption and power pressure upon business;

- Introducing the policy of openness and interaction with the world community;

- Setting up the all-round development of the e-government and electronic democracy;

- Increasing the funding of science and Research and Development (R\&D) sector, increasing the efficiency of educational and scientific infrastructure.

The innovative potential of economy of Russia estimated at the macroeconomic level in general has on average a downward tendency on the majority of the key positions. However, some of its components, in particular the level of development of electronic services and ICT infrastructure, number of patent requests for inventions tend to growth that on condition of effective use of enormous natural and resource potential, and also the capacious domestic market and the developed transport infrastructure can become a basis for innovative development of the economy if managed and used properly.

\section{REFERENCES}

Abdrakhmanova G. I., Gorodnikov N. V., Gokhberg L. M., et al. (2016). Science. Innovations. Information society: 2015: short statistical collection. Moscow, Higher School of Economics National Research University.

Abrhám, J., Bilan, Y.; Krauchenia, A. \& Strielkowski, W. (2015). Planning horizon in labour supply of Belarusian small entrepreneurs. Economic Research - Ekonomska Istraživanja, 28(1), 773-787. doi:10.1080/1331677X.2015.1084238

Akhtyamov, M. K. (2009). A threefold spiral in domestic innovative system: transition with macro - on the micro level, Bologna Process: implementation of competence-based approach in education, Yekaterinburg: UGTU-UPI.

Batkovsky, M. (2009). Osobennost of innovative development of economy of Russia in modern conditions. Resources. Innovation. Supply. Competition, 4, 159-161.

Cábelková, I., \& Strielkowski, W. (2013). Is the level of taxation a product of culture? A cultural economics approach. Society and Economy, 35(4), 513-529. doi:10.1556/SocEc.2013.0007

Christensen, C. M. (2004). Dilemma of the innovator: as because of new technologies the strong companies. Moscow: Alpina Business of Axle boxes.

Christensen, C. M. (2010). Disrupting class: how disruptive innovation will change the way the world learns. N. Y.: McGraw-Hill Education.

Chernov, V., Dorokhova, L., \& Dorokhov, O. (2016). Fuzzy Approach to Estimates Entropy and Risks for Innovative Projects and Programs. Montenegrin Journal of Economics, 12(3), 55-68.

Druker, P. F. (2007). Management tasks in the XIX century. Moscow: Williams.

Etzkowitz, H., \& Leydesdorff, L. (2000). The dynamics of innovation: from National Systems and "Mode 2" to a Triple Helix of university-industry-government relations. Research policy, 29(2), 109-123.

Federal agency on science and innovations of the Russian Federation (2016). Retrieved from: http://www.fasi.gov.ru/. 
Federal State Statistics Service (2008). Central base of statistical data. Retrieved from: http://www.gks.ru/dbscripts/Cbsd/DBInet.cgi.

Fedorayev, S. V. (2010). Innovative potential: content, structure, assessment technique. Retrieved from: http://vestnik.igps.ru/wp-content/uploads/V22/5.pdf

Fedotovsky, A. Yu. (2009). Development of an evaluation method of cost efficiency of innovative project management in a construction industry. Problems of modern economy, 29(1), 516-517.

Gareyev, T. F. (2005). Transfer of technologies and diffusion of innovations as elements of innovative process. Innovations and entrepreneurship: Alliance of Media. Retrieved from: http://www.innovbusiness.ru/content.

Global Competitiveness Report (2010). Retrieved from: http://www.weforum.org.

Groot, B., \& Franses, P. H. (2009). Cycles in basic innovations. Technological Forecasting and Social Change, 76(8), 10211025.

Gunin, V. N. (2000). Innovative activity of the entities: essence, content, forms. Herald of TISBI, 102.

Hochberg, L.M. (2004). Innovation management. Moscow: UNITY-DANA.

Holguin, M.V., \& Bodnar, V.A. (2011). Innovative potential of an economic system and its assessment. Modern technologies of management, 1(1). Retrieved from: http://sovman.ru/article/0101/.

Humanitarian encyclopedia (2010). A rating of the countries of the world on the level of perception of corruption. Center of humanitarian technologies. Retrieved from: http://gtmarket.ru/ratings/corruption-perceptions-index/info

Hummer, M., \& Champy J. (2007). Reengineering of corporation: the manifesto of revolution in business. Retrieved from: http://www.iteam.ru/publications/consulting.

Joint publication of OECD and Eurostat (2006), Management of Oslo: Recommendations about collection and analysis of data on innovations, Retrieved from: https://www.oecd.org/sti/inno/2367580.pdf.

Kokurin, D. I. (2001), Innovative activities, M.: Examination, 573 p.

Korneeva, E. (2016), Ways of improving the comprehensive staff management system in service companies. Bulletin of the Volga State University of Service. Series: Economy, 1(43), 116-123.

Korchagin, P., Korneeva, E., \& Nikitina, N. (2015). Factors that Influence the Effectiveness of Russian Telecommunication Companies. Economics \& Sociology, 8(3), 119-130. doi:10.14254/2071-789X.2015/8-3/9

Koudelková, P., Strielkowski, W., \& Hejlová, D. (2015). Corruption and System Change in the Czech Republic: Firmlevel Evidence. DANUBE: Law and Economics Review, 6(1), 25-46. doi:10.1515/danb-2015-0002

Kraineva, R. (2013). Modern approaches to management of organizations in knowledge economy. Bulletin of the Volga State University of Service, 1, 122-126.

Leydesdorff, L. (2000). The triple helix: an evolutionary model of innovations. Research Policy, 29, 243-255.

Lisin, E., \& Strielkowski, W. (2014). Modelling new economic approaches for the wholesale energy markets in Russia and the EU. Transformations in Business and Economics, 13(2B), 566-580.

Lundvall, B. (2010). National Systems of Innovation: Toward a Theory of Innovation and Interactive Learning. N.Y.: Anthem Press.

Mamedov, O., Movchan, I., Ishchenko-Padukova, O., \& Grabowska, M. (2016). Traditional Economy: Innovations, Efficiency and Globalization. Economics \& Sociology, 9(2), 61-72. doi:10.14254/2071-789X.2016/9-2/4.

Materials of the official site of the Ministry of Economic Development of the Russian Federation (2015). Retrieved from: http://www.economy.gov.ru/minec/main

Matveykin V. G., Dvoretsky S. I., et al. (2007). Innovative potential: current state and prospects of development: monograph. Moscow: Mashinostroyeniye-1 publishing house.

Mishchuk, H., Bilan, Y., \& Pavlushenko, L. (2016). Knowledge Management Systems: Issues in Enterprise Human Capital Management Implementation in Transition Economy. Polish Journal of Management Studies, 14(1), 163173.

Mostenska, T. L., Bilan, Y. V., \& Mostenska, T. G. (2015). Risk management as a factor ensuring enterprises' economic security. Aktual'ni Problemy Ekonomiky = Actual Problems in Economics, 170(8), 193-203.

Nagornyak, G., \& Vovk, Y. (2012). Rol derzhavnoi innovatsiinoi polityky u zabezpechenni rozvytku ekonomiky Ukrainy [The role of the state innovation policy to ensure economic development of Ukraine]. Social'noekonomični problemi i deř̌ava, 6(1), 202-209.

Omonov, Z. K., \& Veretennikova, A. Y. (2016). Quantitative Scaling of Social Innovations. Montenegrin Journal of Economics, 12(4), 77-86.

Overdorf, M. (2007), Harvard Business Review on Innovation. Harvard Business School Press. 
Prigozhin, A. I. (2003). Methods of development of the organizations. Moscow: MTsFER.

Remote consulting: portal of remote consultation of small entrepreneurship (2013). Retrieved from: http://www.distcons.ru/modules/innova/section6.html.

Report Global Competitiveness (2010). Retrieved from: https://www.weforum.org/

Reymer, V. V., \& Kokuytseva, T.V. (2010). International rating of innovative capacity of Russia. Russian entrepreneurship, 12(174), 4-10.

Rosenthal, O. (2010). Management of innovations - a new subject of the European standardization, 4, 30-34.

Stepanenko, D. M. (2004). Classification of innovations and its standardization. Innovations, 7, 77-79.

Strategy of 2020 (2008). Retrieved from: http:/ /archive.kremlin.ru/text/appears/ 2008/02/159528.shtml.

Strielkowski, W., Tumanyan, Y., \& Kalyugina, S. (2016). Labour Market Inclusion of International Protection Applicants and Beneficiaries. Economics \& Sociology, 9(2), 293-302. doi:10.14254/2071-789X.2016/9-2/20

Strielkowski, W., \& Weyskrabova, B. (2014). Ukrainian labour migration and remittances in the Czech Republic. Tijdschrift voor economische en sociale geografie, 105(1), 30-45. doi:10.1111/tesg.12052

The website about nanotechnologies No. 1 in Russia (2014). Retrieved from: http:/ /www.nanonewsnet.ru.

Tolmacheva, O. V. (2011). The directions of innovative development of the Russian industrial enterprises taking into account regularities of expansion of technological ways. Resources. Information. Supply. Competition, No. 1, pp. 199207.

Trott, P. (2008). Innovation management and new product development. United Kingdom: Pearson Education Limited.

Trukhachev, V. I., Mazloev, V. Z., Sklyarov, I. Y., Sklyarova, Y. M., Kalugina, E. N., \& Volkogonova, A. V. (2016). The Strategic Directions of Innovative Economy Development in Russian Agribusiness. Montenegrin Journal of Economics, 12(4), 97-111.

Vasyuhin, O. V., \& Levina, M. I. (2015). Assessment of innovative potential of economic systems of the Russian Federation. Basic researches, 8(2), 349-351.

World Bank (2015). Economic Indicators. Retrieved from: http://web.worldbank.org.

Zizlavsky, O. (2016). The Use of Financial and Nonfinancial Measures within Innovation Management Control: Experience and Research. Economics \& Sociology, 9(4), 41-65. doi:10.14254/2071-789X.2016/9-4/3 